R. Gean Hubbard is Russell L. Corson peofesser of economics ond finance at Columbia University. The athor is grateful to Allen Berger, Phillip Cagan, Rithard Contor, Mark Gertler, Simon Gildrist, Anil lastuyap, Don Morgan, Glean Rudebusch, Brute Smith and participants at the conference for helpful comments and suggestions. The author also acknowledges financial support from the Center for the 5 tudy of the Economy and the State of the Iniversity of Chicago, and the Federal Reserve Bank of New York.

\section{Is There a "Credit Channel" for Monetary Policy?}

\section{R. Clenn Hubbard}

1. nderstanding the channels through which monetary policy affects economic variables has long been a key research topic in macroeconomics and a central element of economic policy analysis. At an operational level, a "tightening" of monetary policy by the Federal Reserve implies a sale of bonds by the Fed and an accompanying reduction of bank reserves. One question for debate in academic and public policy circles in recent years is whether this exchange between the central bank and the banking system has consequences in addition to those for open market interest rates. At the risk of oversimplifying the debate, the question is often asked as whether the traditional interest rate or "money view" channel presented in most textbooks is augmented by a "credit view" channel.'

There has been a great deal of interest in this question in the past several years, motivated both by developments in economic models (in the marriage of models of informational imperfections in corporate finance with raditional macroeconomic models) and recent events (for example, the so-called credit crunch during the $1990-91$ recession). ${ }^{7}$ As 1 elaborate below, however, it is not always straightforward to define a meaningful credit view alternative to the conventional interest rate transmission mechanism. Similar diffculties arise in structuring empirical tests of credit view models.

This paper describes and analyzes a broad, though still well-specified, version of a credit view alternative to the conventional monetary transmission mechanism. In so doing, I sidestep the credit view language per se, and instead focus on isolating particular frictions in financial arrangements and on developing testable implications of those frictions. To anticipate that analysis a bit, 1 argue that realistic models of "financial constraints" on firms' decisions imply potentially significant effects of monetary policy beyond those working through conventional interest rate channels. Pinpointing the effects of a narrow "bank lending" channel of monetary policy is more difficult, though some recent models and empirical work are potentially promising in that regard.

I begin by reviewing the assumptions and implications of the money view of the monetary transmission mechanism and by describing the assumptions and implications of models of financial constraints on borrowers and models of bank-dependent borrowers. The balance of the article discusses the transition from alternative theoretical models of the transmission mechanism to empirical research, and examines implications for monetary policy.

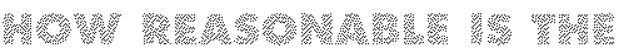

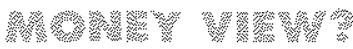

Before discussing predictions for the effects of altemative approaches on monetary policy, it is useful to review assumptions about intermediaries and borrowers in the traditional interest rate view of the monetary transmission mechanism. In this view, financial intermediaries (banks) offer no special services on the asset side of their balance sheet. On the liability side of their balance sheet: banks perform a special role: The banking system creates money by issuing demand deposits. Underlying assumptions about borrowers is the idea that capital structures do not influence real decisions of borrowers and lenders, the result of Modigliani and Miller (1958). Applying the intuition of the Modigliani and Miller theorem to banks, Fama (1980) reasoned that shifts in the public's portfolio preferences among bank deposits,

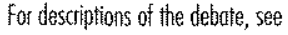
Bernonke and lilinder (1989) ant Bernonke (1993).

? For an andysis of the "caetit crend:" episode, see Kliesent and Totom (1992) and the studies in the Federd Reserve Bunk of New York (1994). The papes by Contor and Rodrigues in the kew York Fed sudies considers the possibility of o credit: crunch for nonbalk intemente dionies.
} 
${ }^{3}$ Foma's insight amplifes the eorlier contritutution of Breinard ated Totht (1963) thot menetary poiry can be andized through its effects on investor portfalios

${ }^{4}$ More generdlyy in a roodel with many assets, this description would arsignt to the money view of the tronsmission mechonisme efferts on spending wising form ony changes in the relotive prices of assets.

White this simple two-asset-motet description of the money view is highty stylized, it is consistant with a nurntere of alternotive models beyond the texthook 1S LM model (see, for exampte, fublotu, 1994), iacluting dynomic equilibrium cost:in-rdvance models for example, Rotenberg, 1984; and Chistiono and Echenbaurn, 1992).

${ }^{5}$ For on empirical description of this

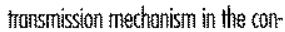
text of the Federal Reserve's forecast. ing riodel, see Mouskopt (1990).

"See, for exomple, "Irinted portitr pation" modets as in Lucos (1990) and Chisiono and Eichenhaum (1992).

'See, for example, andyses of inveritory investment in Kashyag, Stein and Witcox (1993) and Gertler and Gilthris (1993). See also the review of empirical shodies of business fixed investment in Chivinko (1993) and Cumnins, Hassett and Hubbosd (1994).

${ }^{8}$ This current fashion actually has a

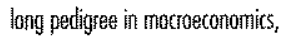
with importunt contributions by Ficher (1933), Gurley and Show (1955, 1960). Minsky (1964, 1975) and Woinilower (1980). Some exonomettic fosecusting models have also focused on financial factors in propagation mechenisns (see, for example the description tor the DRI motel in Eckstein and Sinai, 1986). Cagon (1972) provides of empiritcol andeysis of money and benk tending yews. An ecrly contributor to the contemporary credit view literoture is Bennanke \{1983\}) bonds or stocks should have no effect on real outcomes; that is, the financial system is merely a veil ${ }^{3}$

To keep the story simple, suppose that there are two assets-money and bonds. ${ }^{4}$ In a monetary contraction, the central bank reduces reserves, limiting the banking system's ability to sell deposits. Depositors (households) must then hold more bonds and less money in their portfolios. If prices do not instantaneously adjust to changes in the money supply, the fall in household money holdings represents a decline in real money balances. To restore equilibrium, the real interest rate on bonds increases, raising the user cost of capital for a range of planned investment activities, and interest-sensitive spending falls.'

While the money view is widely accepted as the benchmark or "textbook" model for analyzing effects of monetary policy on economic activity, it relies on four key assumptions: (1) The central bank must control the supply of "outside money," for which there are imperfect substitutes; (2) the central bank can affect real as well as nominal short-term interest rates (that is, prices do not adjust instantaneously); (3) policy-induced changes in real short-term interest rates affect longer-term interest rates that influence household and business spending decisions; and (4) plausible changes in interest-sensitive spending in response to a monetary policy innovation match reasonably well with observed output responses to such innovations.

In this stylized view, monetary policy is represented by a change in the nominal supply of outside money. Of course, the quantity of much of the monetary base is likely to be endogenous. Nonetheless, legal restrictions (for example, reserve requirements) may compel agents to use the outside asset for some transactions. In practice, the central bank's influence over nominal short-term interest rates (for example, the federal funds rate in the United States) is uncontroversial. There is also evidence that the real federal funds rate responds to a shift in policy (see, for example, Bernanke and Blinder, 1992).

Turning to the other assumptions, that long-term tates used in many saving and investment decisions should increase or decrease predictably in response to a change in short-term rates is not obvious a priori based on conventional models of the term structure. Empirical studies, however, have documented a significant, positive relationship between changes in the (nominal) federal funds rate and the 10-year Treasury bond rate (see, for example, Cohen and Wenninger, 1993; and Estrella and Hardouvelis, 1990). Finally, although many components of aggregate demand are arguably interest-sensitive (such as consumer durables, housing, business fixed investment, and inventory investment), output responses to monetary innovations are large relative to the generally small estimated effects of user costs of capital on investment.'

I shall characterize the money view as focusing on aggregate, as opposed to distributional, consequences of policy actions. In this view, higher default-risk-free rates of interest following a monetary contraction depress desired investment by firms and households. While desired investment falls, the reduction in business and household capital falls on the least productive projects. Such a view offers no analysis of distributional, or cross-sectional, responses to policy actions, nor of aggregate implications of this heterogeneity. I review these points not to suggest that standard interest rate approaches to the monetary transmission mechanism are incorrect, but to suggest strongly that one ought to expect that they are incomplete.

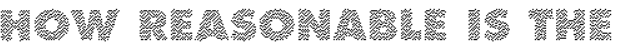

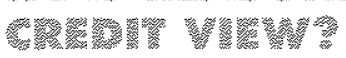

The search for a transmission mechanism broader than that just described reflects two concerns, one "macro" and one "micro." The macro concern, mentioned earlier, is that cyclical movements in aggregate demandparticularly business fixed investment and inventory investment-appear too large to be explained by monetary policy actions that have not generally led to large changes in real interest rates. This has pushed some macroeconomists to identify financial factors in propagating relatively small shocks, factors that correspond to accelerator models that explain investment data relatively well. ${ }^{B}$ Indeed, I use the term "financial acceleratot" (put forth by Bernanke, Gertler and Gilchrist, 
forthcoming) to refer to the magnification of initial shocks by financial market conditions.

The micro concern relates to the emergence of a growing literature studying informational imperfections in insurance and credit markets. In this line of inquiry, problems of asymmetric information between borrowers and lenders lead to a gap between the cost of external finance and internal finance. The notion of costly external finance stands in contrast to the more complete-markets approach underlying the conventional interest rate channels, which does not consider links between real and financial decisions."

Although a review of this literature is beyond the scope of this article, I want to mention three common empirical implications that have emerged from models of the financial accelerator. ${ }^{10}$ The first, which I just noted, is that uncollateralized external finance is more expensive than internal finance. Second, the spread between the cost of extemal and internal finance varies inversely with the borrower's net worth-internal funds and collateralizable resources-relative to the amount of funds required. Third, an adverse shock to a borrower's net worth increases the cost of external finance and decreases the ability of the borrower to implement investment, employment and production plans. This channel provides the financial accelerator, magnifying an initial shock to net worth. (See, for example: Fazzari, Hubbard and Petersen, 1988; Gertler and Hubbard, 1988; Cantor, 1990; Hoshi, Kashyap and Scharfstein, 1991; Calomiris and Hubbard, forthcoming; Hubbard and Kashyap, 1992; Oliner and Rudebusch, 1992; Fazzari and Petersen, 1993; Hubbard, Kashyap and Whited, forthcoming; Bond and Meghir, 1994; Cummins, Hassett and Hubbard, 1994; Carpenter, Fazzari and Petersen, 1994; and Sharpe, 1994.)" Links between internal net worth and broadly defined investment (holding investment opportunities constant) have been corroborated in a number of empirical studies. ${ }^{12}$

Let me now extend this argument to include a channel for monetary policy. In the money view, policy actions affect the overall level of real interest rates and interest-sensitive spending. The crux of models of information-related financial frictions is a gap between the cost of external and internal finance for many borrowers. In this context, the credit view offers channels through which monetary policy (open market operations or regulatory actions) can affect this gap. That is, the credit view encompasses distributional consequences of policy actions, because the costs of finance respond differently for different types of borrowers. Two such channels have been discussed in earlier work: (1) financial constraints on borrowers and (2) the existence of bank-dependent borrowers.

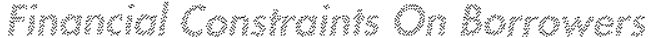

Any story describing a credit channel for monetary policy must have as its foundation the idea that some borrowers face high costs of external finance. In addition, models of a financial accelerator argue that the spread between the cost of external and internal funds varies inversely with the borrowers' net worth. It is this role of net worth which offers a channel through which policy-induced changes in interest rates affect bortowers' net worth (see, for example, Gertler and Hubbard, 1988). Intuitively, increases in the real intetest rate in response to a monetary contraction increase borrowers' debt-service burdens and reduce the present value of collateralizable net worth, thereby increasing the marginal cost of external finance and reducing firms' ability to carry out desired investment and employment programs. This approach offers a credit channel even if open market operations have no direct quantity effect on banks' ability to lend. Moreover, this approach implies that spending by lownet-worth firms is likely to fall significantly following a monetary contraction (to the extent that the contraction reduces borrowers' net worth)

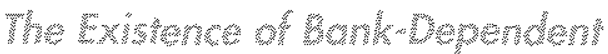 Frow}

The second channel stresses that some borrowers depend upon banks for external funds, and that policy actions can have a direct impact on the supply of loans. When banks are subject to reserve requirements on liabilities, a monetary contraction drains reserves,
"Potentide effecis of udverse selartiost problems on maket allocation have been oddessed in imporicant pepers by Aketof (1970) and Rothschild and Sigigliz (1976), and hove been applied fo laan makets by Juffee and Iussell (7976) and Stijelitz arial Weiss (1981), ond to equity morkets by hyers and Moiluf (1984). Resercth on principerk-regent problems in finance has followed the contitibution of Jensen and Heckling (1976). Gertler (1988), Bermanke (1993) and Kirag and Levine (1993) provide reviews of reloted models of informational inperfections in copital markets.

17 See also the seviow in Benranke, Gerter and Gikhist (forthoming). These implications are consistent with o wide doss of nodels, indest ing those of lowisend (1979), Binder and 5itilitz (1983), Famter (1985), whtiomson (1987), Bernanke and Gertles (1989. 1990), Golomitis and Hubbad (1990), Sharae (1990), Hete and hoose (1991), Kiveruks and Mone (1993), Gatter (1992), Greenwold and Stigitiz (9988, 1993) and Lanond (1993).

11 For households, Misskin (1977, 1978) and Zeldes (1989) provide evidence of effectss of hoursehold balance sheet conditions on consumer expenditures.

is The ofopendix presents a simple model that il istofotes these predicfions.

Fol brooder descriptions of credit view duguments, see Benonoke (1993), Friedmonat and Kutther (1993), Gertler (1993), Gertler and Gilchist (1993) and Kashyop and Stein (1994). An eatly exposition of a fole for crediti owilobility oppens in Roosi (1951). 


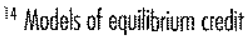
rotioning under adverse selection (for excomple, Stightz and Weiss, 1981) offer onother mechonism tirough which on incease in the level of defoutitisk-fee renl interest rates reduces loon sapply. Gredit rationing is not requised for the bank dependentbornower channel to be operative. Instend, what is required is that loans to these bor rowers ofe on imperfect substitute for raterer assets and that the bar rowers lock alternative soures of finonce.

(5) Colomitis ond Kath (1991) offer o model of derrantentable debt to finance bunk lending.

${ }^{16}$ A substantial bady of entiniried evidence supports the ideo that benks offer sperid services in the lending process. For example, James (1987) and Lammer and Mccoinell (1989) fitet that the onnouncerneret of a bonk loofn, all else equal, roises the shove pice of the borowing firm, likely eflecting the infornation content of the bank's assessment. In a sintilus spirit, Famo (1985) ond Janes (1987) find that banks' borrowers, rather thon banks' depositors, bear the incidence of reserve requisements lindicaing that borrowers Inust foo hove ensy access to ofter sauces of funds). Pefersen and Rajus (1994) show thot small businesses tend to rely on locel bonks for extendi funds.

${ }^{17}$ See, for example, the discussion in Patessera ond Roijar (1994)

${ }^{78}$ Owens and Schreft (1992) diseuss the identificotion of "sedit crundtes." See also the descciplition int Hubbard (1994). possibly decreasing banks' ability to lend. As a result, credit allocated to bank-dependent borrowers may fall, causing these borrowers to curtail their spending. In the IS-LM framework of Bernanke and Blinder (1988), both the 15 and LM curves shift to the left in response to a monetary contraction. Alternatively, an adverse shock to banks' capital could decrease both banks' lending and the spending by bank-dependent borrowers. Such bank lending channels magnify the decline in output as a result of the monetary contraction, and the effect of the contraction on the real interest rate is muted. This basic story raises three questions, relating to: (1) why certain borrowers may be bank-dependent (that is, unable to access open market credit or borrow from nonbank financial intermediaries or other sources), (2) whether exogenous changes in banks' ability to lend can be identified, and (3) (for the analysis of open market operations) whether banks have access to sources of funds not subject to reserve requirements.

The first question is addressed, though not necessarily resolved, by the theoretical literature on the development of financial intermediaries ${ }^{14}$. In much of this research (see especially Diamond, 1984; and Boyd and Prescott, 1986), intermediaries offer low-cost means of monitoring some classes of borrowers. Because of informational frictions, non-monitored finance entails deadweight spending resources on monitoring. A free-tider problem emerges, however, in public markets with a large number of creditors. The problem is mitigated by having a financial intermediary hold the loans and act as a delegated monitor. Potential agency problems at the intermediary level are reduced by having the intermediary hold a diversified loan portfolio financed principally by publicly issued debt. ${ }^{15}$ This line of research argues rigorously that borrowers for whom monitoring costs are significant will be dependent upon intermediaries for external finance, ${ }^{16}$ and that costs of switching lenders will be high." It does not, however, necessarily argue for bank dependence (for example, finance companies are intermediaries financed by non-deposit debt).

Second, even if one accepts the premise that some borrowers are bank-dependent in the sense described earlier, one must identify exogenous changes in banks' ability to lend. Four such changes have been examined in previous research. The first focuses on the role played by banking panics, in which depositors' flight to quality - converting bank deposits to currency or government debtreduces banks' ability to lend (for empirical evidence, see Bernanke, 1983, and Bernanke and James, 1991, for the 1930s and Calomiris and Hubbard, 1989, for the National Banking period).

A second argument emphasizes regulatory actions, such as that under binding Regulation $Q$ ceilings in the United States (see, for example, Schreft, 1990; Kashyap and Stein, 1994; and Romer and Romer, 1993) and regulation of capital adequacy (see, for example, Bernanke and Lown, 1992; and Peek and Rosengren, 1992). ${ }^{18}$ Empirical evidence for this channel is quite strong. Third, Bizer (1993) suggests that increased regulatory scrutiny decreased banks' willingness to lend in the early 1990s, all else equal.

The fourth argument stresses exogenous changes in bank reserves as a result of shifts in monetary policy. In principle, such a shift in monetary policy could be identified with a discrete change in the federal funds rate in the aftermath of a dynamic open market operation or with a change in reserve requirements. Because the effects on reserves of changes in reserve requirements are generally offset by open market operations, bank-lending channel stories are generally cast in terms of open market operations.

An illustration of the gap between models and practice surfaces in addressing the third question of the ease with which banks can raise funds from non-deposit sources (for example, CDs), when the Fed decreases reserves. Romer and Romer (1990) have pointed out, for example, that if banks see deposits and CDs as perfect substitutes, the link between open market operations and the supply of credit to bank-dependent borrowers is broken. Banks are unlikely, however, to face a perfectly elastic supply schedule for CDs at the prevailing CD interest rate. Since large-denomination CDs are not insured at the margin by federal deposit insurance, prospective lenders must ascertain the quality of the issuing bank's portfolio. Given banks' private information about at 
least a portion of their loan portfolio, adverse selection problems will increase the marginal cost of external finance as more funds are raised (see, for example, Myers and Majluf, 1984; and Lucas and McDonald, 1991). In addition, as long as some banks face constraints on issuing CDs and those banks lead to bank-dependent borrowers, a bank lending channel will be operative.

While the foregoing discussion centers on open market operations, regulatory actions by the central bank-credit controls, for example-represent another way in which monetary policy can have real effects through influencing the spending decisions of bankdependent borrowers. Here the effects are likely to be more pronounced than for the case of open market operations, since the question of the cost of non-deposit sources of funds is no longer central, and the effectiveness of such regulatory actions depends only on the existence of bank-dependent borrowers.

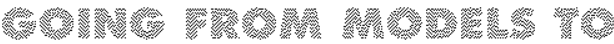

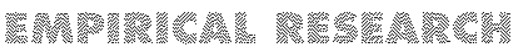

Both the financial-constraints-on-borrowers and bank-lending-channel mechanisms imply significant cross-sectional differences in firms' shadow cost of finance and in the response of that cost to policy-induced changes in interest rates. Accotdingly, empirical researchers have attempted to test these cross-sectional implications. As I examine this literature, 1 explore how Modigliani-Miller violations for nonfinancial borrowers, financial intermediaries or both offer channels for monetary policy beyond effects on interest rates. The appendix frames this discussion using a simple model; an intuitive presentation follows.

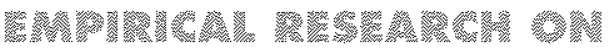

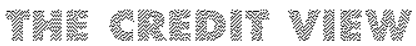

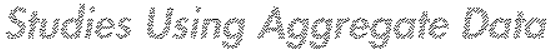

The microeconomic underpinnings of both financial accelerator models and the credit view of monetary policy hinge on certain groups of borrowers (perhaps including banks or other financial intermediaries) facing incomplete financial markets. Examining links between the volume of credit and economic activity in aggregate data (with an eye toward studying the role played by bankdependent borrowers) requires great care. Simply finding that credit measures lead output in aggregate time-series data is also consistent with a class of models in which credit is passive, responding to finance expected future output (as in King and Plosser, 1984). Consider the case of a monetary contraction, for example. The effect of the contraction on interest rates could depress desired consumption and investment spending, reducing the demand for loans.

In a clever paper that has stimulated a number of empirical studies, Kashyap, Stein and Wilcox (1993)-henceforth, KSWexamine relative fluctuations in the volume of bank loans and a close open market substitute, issuance of commercial paper. In the KSW experiment, upward or downward shifts in both bank lending and commercial paper issuance likely reflect changes in the demand for credit. However, a fall in bank lending while commercial paper issuance is rising might suggest that bank loan supply is contracting. To consider this potential comovement, $\mathrm{KSW}$ focus on changes over time in the mix between bank loans and commercial paper (defined as bank loans divided by the sum of bank loans and commercial paper). They find that, in response to increases in the federal funds rate (or, less continuously, at the times of the contractionary policy shifts identified by Romer and Romer, 1989), the volume of commercial paper issues rises, while bank loans gradually decline. They also find that policy-induced changes in the mix have independent predictive power for inventory and fixed investment, holding constant other determinants. ${ }^{19}$

The aggregate story told by KSW masks significant firm-level heterogeneity, however. The burden of a decline in bank loans following a monetary contraction is borne by smaller firms (see Gerter and Gilchrist, 1994). ${ }^{20}$ Moreover, the evidence in Oliner and Rudebusch (1993) indicates that once trade credit is incorporated in the definition of small firms' debt and once firm size is held
${ }^{19}$ Other ond Rudebusth (1993) and Friedman and Kutther (1993) have disputed the KSW interpretation of the mix os measuting is substitution betweert bank loans and conmer. ciol proper. They argue that, during a fecession, shifts in the raix are exploined by an increase in commercid paper issuance rather than by a decrease in bonk loons.

26 Mogan (7993) finds o siniler restult in on andysis of toon comt ristaneats. After an episode of monetary contuation, firms without loan commitments receive a smaler stiden of batk lears. 
constant, monetary policy changes do not alter the mix.

It also does not appear that bank-dependent borrowers switch to the commercial paper market lollowing a monetary contraction. Instead, the increase in commercial paper issuance reflects borrowing by large firms with easy access to the commercial paper market, possibly to smooth fluctuations in their flow of funds when earnings decline (Friedman and Kuttner, 1993) or to finance loans to smaller firms (Calomiris, Himmelberg and Wachtel, forthcoming).

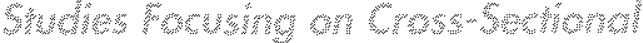

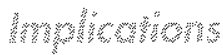

${ }^{2}$ Towad this end, nore diect com. forisons of borrowing by bankdependent oud andank dependent borrowers have been offered. Usiag fintlesel doto, Kashyop, Lomont ond Stein (1994) benceforth 115 -follow the Fozzoni, Hubbard and Petersen (1989) approach of chassifying

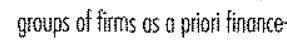

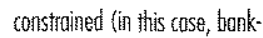
dependent) or not. In particutur, they study iaventory investneat by pubisily sroded firmes with and without bond ratings, os a peoxy for bonk depentence. Focusing on the 1982 recession (os an indirect medas of ideritilying a pertod following of figit money episode), they find that investory invesfnent by non-tied firmis was influenced. Dil else equal, by the firms' own cosh holdings, an effect not pesesent for the inventory investment by roted firms. In subsequent boom yeurs (which KLS identify with of ensy money episode), fhey find li: 挑 effect of cosh holdings on inventopy investment lor eithes non-roted or rated componies. These patterns lead KLS to conctede thot o bank leading chanel was operative in response to the monetay conteacfich. However, the al $\mathrm{S}$ results are consistert with o mere general model in which low-net-woth fims face moge costly exsernal finance in downterns.
More convincing empirical tests focus on the cross-sectional implication of the underlying theories-namely that creditmarket imperfections affect investment, employment or production decisions of some borrowers more than others. At one level, existing cross-sectional empirical studies have been successful: There is a substantial body of empirical evidence documenting that proxies for borrowers' net worth affect investment more for low-net-worth borrowers than for high-net-worth borrowers (holding constant investment opportunities). This suggests that, to the extent that monetary policy can affect borrowers' net worth, pure interest rate effects of open market operations will be magnified.

The second body of empirical analysis of information-related imperfections focuses on the effects of monetary policy on borrowers' balance sheets. Gertler and Hubbard (1988) conclude that, all else equal, internal funds have a greater effect on investment by nondividend-paying firms during recessions. The evidence of Gertler and Gilchrist (1994) is particularly compelling here. Analyzing the behavior of manufacturing firms summarized in the Quarterly Financial Reports data, Gertler and Gilchrist consider differences in small and large firms' responses to tight money (as measured by federal funds tate innovations or the dates identified by Romer and Romer, 1989). In particular, small firms' sales, inventories and short-term debt decline relative to those for large firms over a two-year period following a monetary tightening, results consistent with the financial accelerator approach. They also demonstrate that the effects of shifts in monetary policy on the small-firm variables are shatper in periods when the small-firm sector as a whole is growing more slowly, also consistent with the financial accelerator approach. Finally, they show that the ratio of cash flow to interest expense (a measure of debt-service capacity) is associated positively with inventory accumulation for small, but not for large, manufacturing firms.

The Gertler and Gilchrist results, which are very much in the spirit of the earlier cross-sectional tests of financial accelerator models, have been borne out for studies of fixed investment by Oliner and Rudebusch (1994) and for inventory investment by Kashyap, Lamont and Stein (1994). ${ }^{27}$ In addition, Ramey (1993) shows that, for forecasting purposes, the ratio of the sales growth of small firms to that for large firms offers significant information about future GDP.

Finally, using the firm-level data underlying the aggregates summarized in the Quarterly Financial Reports, Bernanke, Gertler and Gilchrist (forthcoming) analyze the differences in sales and inventories between large and small manufacturing firms by two-digit industry. They find that fluctuations in the large firm-small firm differences are roughly the same size as fluctuations in the corresponding aggregate fluctuations for the manufacturing sector. Because small firms' sales (as they defme small firms) comprise about one-third of the sales of the manufacturing sector, roughly one-third of cyclical fluctuations in manufacturing sales can be explained by large firm-small firm differences.

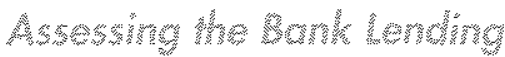 Chomet}

While the principal empirical predictions of the financial accelerator approach have been corroborated in micro-data studies and lownet-worth firms appear to respond differentially to monetary contractions, the question of the role of banks remains. I consider this question below in three steps.

First, is there evidence of significant 
departures from Modigliani and Miller's results for certain groups of banks in the sense that have been identified for firms? Second, is there evidence that small- or lownet-worth firms are more likely to be the loan customers of such banks? Finally, do low-net-worth firms have limited opportunities to substitute credit from unconstrained financial institutions when cut off by constrained financial institutions?

\section{Aoplying the Modighan and Moller Theoren bor buks}

Kashyap and Stein (1994) apply the intuition of the models of effects of internal net worth on investment decisions by nonfinancial frrms to study financing and lending decisions by banks. This is an important line of inquiry in the bank lending channel research agenda, because it addresses the ease with which banks can alter their fnancing mix in response to a change in bank reserves and the effect of changes in the financing mix on the volume of bank lending. Just as earlier studies focused on cross-sectional differences in financing and real decisions of nonfinancial firms of different size, Kashyap and Stein analyze cross-sectional differences in fnancing and lending decisions of banks of different size. To do this, they use data drawn from the quarterly "Call Reports" collected by the Federal Reserve.

Kashyap and Stein construct asset size groupings for large banks (those in the 99th percentile) and small banks (defined as those at or below the 75 th, $90 \mathrm{th}, 95$ th or $98 \mathrm{th}$ percentiles). They first show that contractionary monetary policy (measured by an increase in the federal funds rate) leads to a similar reduction in the growth rate of nominal core deposits for all bank size classes. They find signiffcant heterogeneity across bank size classes, however, in the response of the volume of lending to a change in monetary policy. In particular, a monetary contraction leads to an increase in lending in the short run by very large banks. This is in contrast to a dectine in lending in the short run by smaller banks. These do not simply reflect differences in the type of loans made by large and small banks. A similar pattern emerges when loans are disaggregated to include just commercial and industrial loans.

One possible explanation for the Kashyap and Stein patten is that a monetary contraction weakens the balance sheet positions of small firms relative to large firms. If small firms tend to be the customers of small banks and large firms tend to be the customers of large banks, a fall in loan demand (by small borrowers) for small banks could be consistent with the differential lending responses noted by Kashyap and Stein. To examine this possibility, Kashyap and Stein analyze whether small banks increase their holdings of securities relative to large banks during a monetary contraction. They actually find that small banks' securities holdings are less sensitive to monetary policy than large banks' securities holdings, though the difference in the responses is not statistically significant.

The use of bank size as a measure to generate cross-sectional differences does not correspond precisely to the underlying theoretical models, which stress the importance of net worth. In this context, bank capital may be a better proxy. Peek and Rosengren (forthcoming) analyze the lending behavior of New England banks over the 1990-91 recession. Their results indicate that the loans of well capitalized banks fell by less than the loans of poorly capitalized banks. ${ }^{\text {.t }}$ Hence, as with the Kashyap and Stein findings, their evidence suggests there are effects of informational imperfections in financial markets on the balance sheets of intermediaries as well as borrowers.

\section{Motwhing Borrowers and Lenders}

The last two questions relate to the matching of borrowers and lenders. The former asks whether the firms identified by empirical researchers as finance-constrained are the loan customers of the constrained (small) banks such as those identified by Kashyap and Stein. This line of inquiry requires an examination of data on individual loan transactions, with information on characteristics of the borrower, lender and lending terms. ${ }^{23}$ One could establish whether constrained firms are the customers of constrained banks and whether such firms n2 Using dato on commerrial banks nationwide over the 1979-92 neind, Berge ond Udell (1994) found hto the evidence that the introduction of risktbasei copital requisentents per se affected crestit diloration. Hation, Lning and Wilcox (1994) glso use quartedy doto on individual bonk's portfolalos to estimate tate responsiveness of perfolio composition to dhonges in coipital requilentents They find that "capitat shouffal" institutitines reduced their C\&I loans respense by lorger totol anounts, al else equit, than "anital surplus" institutions.

${ }^{23}$ An

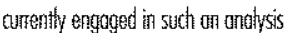


${ }^{27}$ Another possibility is thot the werkened belance sheet positions of many barowers perifitotes 0. "flight to quality" by lenders generally, inceasing the denond for cominnerciol peper issues of logge firms.

${ }^{25}$ The dotes of monetary policy controctians suggested by Romer ond Roner (1989) hove generoted signitiont controversy. Shapiro (1994) orgues, for example, that enpirical evidence fowoss the hypothesis that several Raner dotes ore predictidale using manosires of therraloyment and intlotion as deterrytriants of actions by the Federd Opea Masker Conmeitter; see also the tiscussion in (ecchefti (1995). Hoover ond Perez (1994) offer a nunber of criticissms of the Roterers' approctet,

${ }^{26}$ Suth relotionships are typicolly estimated as:

$Y(f)=a+b Y(t-i)$ $-d(t-\hat{n})-d f(t-n)$

where $Y$ is the pertentuge thange in reel 60 r retative to potentiol $60 P, H$ is the percentuge change in the hightemploynent fedend butget supplas, Fis the chonge in the Iederel funds rote, $t$ is the current time seriod, ond idenotes lags. See, for exconple, Hitte and Kelleher (1990), Pern ond Sonetze (1992) and Cohen and Wenninger (1993).

${ }^{27}$ Cover (1992) finds sill stranger evidence of asymmetaic effects when monetary aggregates are used os the polixy indicator instead of the federal funds sate. switch from constrained banks to unconstrained ones during episodes of monetary contractions. Theories emphasizing the importance of ongoing borrower-lender relationships imply that such switches are costly and unlikely. If true, part of the monetary transmission mechanism takes place through reductions in loan supply by constrained banks.

The latter of the two questions suggests the need to study a broader class of lenders than banks. If borrowers from constrained banks can switch at low cost to nonbank lenders following a monetary contraction, the narrow bank credit channel of monetary policy is frustrated. In this vein, Calomiris, Himmelberg and Wachtel (forthcoming) analyze firm-level data on commercial paper issuance and argue that large, high-quality, commercial paper-issuing firms increase paper borrowings during downturns to finance loans to smaller firms. ${ }^{24}$ They note that accounts receivable rise for paper-issuing firms, supporting the notion that these firms may serve as trade credit intermediaries for smaller firms in some periods. From the standpoint of the bank lending channel, it is important to establish what happens to the costs and terms imposed by these intermediaries. If, on the one hand, such terms are no more costly than bank intermediary finance, then the switch of borrowers from being bank customers to being trade credit customers entails very limited macroeconomic effects. On the other hand, if large, paper-issuing firms accept their intermediary role reluctantly, very costly trade credit may exacerbate a downturn by raising the cost of funds for constrained firms. More empirical investigation of trade credit terms is needed to resolve this question.

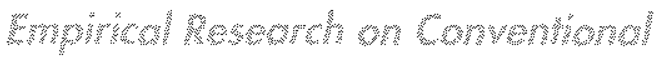

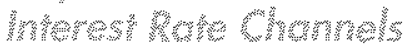

More empirical research is also needed to assess the validity of the basic money view. A central problem is that, while most empirical studies focus on monetary aggregates such as $\mathrm{M} 2$, the theoretical description offered in the first section suggests an emphasis on outside money and, importantly, on com- ponents of outside money over which the central bank can exercise exogenous control. First identifying exogenous changes in monetary policy is difficult. ${ }^{25}$ Recent research by Bernanke and Blinder (1992) and Christiano, Eichenbaum and Evans (forthcoming) offers promising strategies for studying the effects of monetary policy shocks.

In addition, recent analyses of policyreduced-form models document a significant, negative relationship in quarterly data between the percentage change in real GDP relative to potential GDP and the change in the federal funds rate. ${ }^{2 b}$ Such studies must first confront the possibility that the measured interest sensitivity of output reflects links between interest rate and net worth changes for certain groups of borrowers/spenders. A second issue, noted by Morgan (1993) and Cohen and Wenninger (1993), is that quarterly residuals from estimated policy-reduced-form equations display large negative errors during recessions, suggesting the possibility of an asymmetric response of economic activity to increases or decreases in the federal funds rate. Finally, more theoretical and empirical research is needed to examine links between changes in short-term real interest rates (which are significantly influenced by policy actions) and changes in long-term real interest rates (which affect firms' cost of capital).

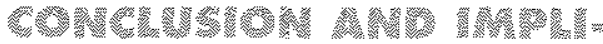

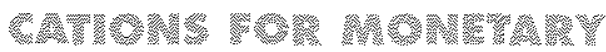

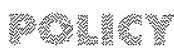

This survey argues that the terms money view and credit view are not always welldefined in theoretical and empirical debates over the transmission mechanism of monetary policy. Recent models of information and incentive problems in financial markets suggest the usefulness of decomposing the transmission mechanism into two parts: one related to effects of policy-induced changes on the overall level of real costs of funds; and one related to magnification (or financial accelerator effects) stemming from impacts of policy actions on the financial positions of borrowers and/or intermediaries.

Two observations emerge clearly from the literature. First, the spending decisions 
of a significant group of borrowers are influenced by their balance sheet condition in the ways described by financial accelerator models. Second, even in the presence of more sophisticated financial arrangements, there are still information costs of screening, evaluation and monitoring in the credit process, imparting a special role for intermediaries (be they banks or other lenders) with cost advantages in performing these tasks. ${ }^{\text {. }}$

The first observation suggests that financial factors are likely to continue to play a role in business fluctuations. The second suggests that regulatory policies affecting information-specializing intermediaries are likely to affect the cost of credit for at least some borrowers. In part because of interest in alternative views of the monetary transmission mechanism and in part because of concern over the effects of institutional change in the financial system, academics and policymakers are analyzing whether the scope for monetary policy to affect real outcomes is becoming narrower. Both observations noted above are consistent with a heightened role for monetary policy in affecting real decisions of firms with weak balance sheet positions. Developing ways to incorporate borrower heterogeneity in both economic models of money and credit and in forecasting is an important, practical task for economic modelers and policymakers.

Whether the simplest bank lending channel-that a fall in banks' reserves following contractionary open market operations decreases both banks' ability to lend and borrowers ability to spend-is operative is not clear, however. More micro-evidence at the level of individual borrower-lender transactions is needed to resolve this question. At the same time, proponents of the simplest characterization of an interest rate channel must address both the cross-sectional heterogeneity in firms' response to monetary policy and the extent to which observed interest rate effects on output reflect differentially large effects of policy on certain classes of borrowers.

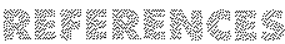

Akerlof, George. "The Market for Lemans: Quality Uncertainty and the Mokket Medhonism," Quorterly Jound of Economics (August 1970), pp. $\$ 88-500$.
Berger, Alien N1, and Gregory F. Idell. "Gid Risk-Based Capitol Allocote Bonk Credit and Couse a 'Credit Crunch' in the U.S.?" (part wo) Journol of Money, Crodit and Bonking (August 1994), pp. 585-628.

Bernanke, Ben S. "Credit in the Macroeconomy," Federal Reserve Bank of Hew Yok Quorterly Review (spring 1993), po. 5070.

"Nonmonetary Effects of the Financial Crisis in the Propagotion of the Great Depsessien," The Americon Economic Review (June 1983), pp. 257-76.

and Alon S. Blinter. "The Federal Funds Rate and the Chonnels of Monetony Iransmission," The American Economic Review (September 1992), pp. 901-2).

and $\quad$.Credt, Money, and Aggregate

Demand," The Americon Economic Review (Moy 1988), gp. 435-39.

and Mork Gertlez. "Ägeney Cost, thet Worth, and Business

Fluctuations," The American Economic Review (March 1989), pp. $14-31$.

and ___ "Financial Frogitity and Economic

Perfomance," Quarterly Journol of fronomics (February 1990), рр. 87- $\$ 14$.

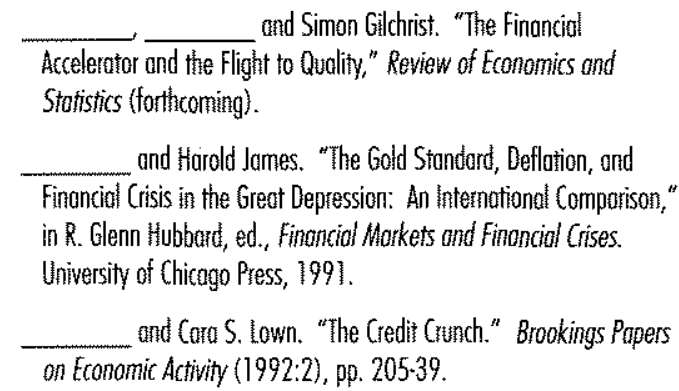

Bizer, Dowid S. "Regutotory liscretion and the Credit Crunth," working poper (April 1993), U.S. Securities and Exdiange Commission.

Blindez, Alon S., and Joseph E. Stoglitz. "Money, Credit Constaints, and Econonic Activity," The Americon Economic Review (May 1983), pp. $297-302$.

Bond, Stephen, and Costas Meghir. "Dynamic Invesiment Modets and the Firm's Finandal Policy," Review of Economit Studes (Agril 1994), pp. 197-222.

Boyd, John H., and Mark Gertler, "Are Bonks Dead? Or, Ase the Reports Geotty Exoggented?" working poper (May 1994), Federat Reserve Bank of Minneapolis.

and Edward Prescots. "Financiat Intemediary-Coatitions,"

Jound of Economic Theory (April 1986), pp. 211-32.

and Buce Q. Smith. "Copital Market Imperfections in a Monetary Gowth Model," Working Poper No. 533 (Augus 1994), Federd Reserve Bonk of Minneopolis.

Broinard, Williom C, and lames Jobin. "Financial Intermediories and the Effectiveness of Monetary Contrels," The Americon Economic Review (Moy 1963), pp. 383-400.

Cagan, Phillip. The Chonnels of Monetary Effects on interest Rotes. Columbin University Press, 1972.

\footnotetext{
${ }^{28}$ For erent andlyses of the future of banking, see Gorton and Pennachi (1993), Edwords (1993) ond Boyd and Getter (1994). Thatnton (1994) discusses likely effects of recent finonidal intovofions on the bank lending chenned.
} 
Calomiris, Ohates W. Chates P. Himmetberg and Pasl Wochtel. "Commercio Paper and Corporote Finance: A Mieroecononic Perspactive, "Comegie-Rochester Conference Series on Public Policy (forthoming).

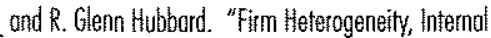
Finance, and 'Credit Rationing," Economic Joumal (Mad 1990), pp. 90104.

and "Price flexibility, Credit Avalubility, and Economic Cluctuctions: Evidence from the Enited States, 18941909," Quortefly Joumd of Economies (August 1989), pp. 429.52.

and "Tax Policy, Internal Finguce, and Investment: Fvidence from the Undistrituted Profits Tox of 1936-37, Jound of Business (forthoming).

and Chatles Katm. "The Role of Demandable Debt in

Structuring Optimal Bonking Arrangements," The Americon Economic Review (June 1991), pp. 497-513.

Contor, Ridord. "Effects of Leveroge on Conporde lnwestment and Hiring Decisions." Federnl Reserve Bank of New York Quaterly Reviaw (summer 1990), pp. 31-41.

ond Anthony P. Rodigues. "Nonbenk Lenders and the Credit Slowdown," in Studies on Causes and Consequences of the 1984-1992 Credit Slowdown, Federtal Reserve Bakk of Now Yok, 1994.

Copentez, Robert, Steven M. Fazzari and Bruce C. Pefersen. "Inventory (Dis)hinestment, Internal Finance Fluctuations, and the Business Cyce," Brookings Popers on Economic Activity (1994:2).

Cecchetit, Stephen G. "Distinguishing Theostes of the Monetory Trunsmission Mechonism," this Review (Moy/linne 1995), pp. $83-100$

Chininko, Robest S. "Business Fixed lwestment Spending; A Criticol Suvey," Jaunal of Economic Literature (December 1993), pp. 1875-911.

Christiano, Lawence, and Martin S. Eichenbaurn. "Liouidity Effects and the Monezary Transmission Mechanism," The Americon Economic Review (Moy 1992), pp. 346-53.

and Charles Evons. "The Effects of Monefary

Policy Shocks: Evidence from the Flow of Funds," Review of Economics and Statistics (fortheoming).

Cohen, Gerdold, and John Wenninger. "The Relotionship Befween the Federd Funds Rate and Economic Activity, werking paper (Decenther 1993), Federd Reserwe Bank of New York

Coved, John Perry. "Asymmetric Effects of Pasitive and Negative Honey Supply Shakks," Ouarterly Jound of Economics (Noventher 1992), pp. 126182

Cummins, Jason G., Kevin A. Herssett and R. Glenn Hubtand. "A Reconsiderotion of Investment Behovior Using Tax Reforms as Noturol Experiments," Brookings Papers on Economic Activity (1994:2), pp. 1.74 .

Diamond, Douglos W. "Finonciol Intemedintion and Delegated Monitoring," Review of Economic Studies (July 1984), pp. 393-414.
Eckstein, Otto, ond Allen Sinis. "The Mechanisms of the Business Cyde in the Postwar Ero," in Robert t. Gordon, ed., The American Business Cyde: Contmuity and Change. University of Chicogo Press, 1986.

Edwords, Frankin R. "Finencial Markets in Transition-Or the Derline of Commercial Banking," in Chonging Copital Markets: Implicotions for Monetary Policy. Federal Reserve Bank of Kanses City, 1993.

Estrella, Arturo, and Gikas Hordouvelis. "Possible gotes of the Yield Cune in Monetory Policy" in Intermediote Torgets and Indicators of Monetory Policy: A Critical Survey, 1990. Federal Reserve Bank of New Yook, 1990, pp. 339-62.

Foma, Eugene F. "Banking in the Theory of Einonce," Jound of Monetary tronomics (Jenuary 1980), ip. 39-57.

Foma, Eugene F. "What's Different About Bonks?" Joumd of Wonetory Economics (June 1985), pp. 29-39.

Foomer, Roger E.A. "Impicit Controcts with Asymmetric Information and Bankrupicy. The Effect of Interest Rates on Layoffs," Review of Economic Studies (Juy 1985), pp. 427-42.

Fozzon, Steven M., and Bruce C. Petersen. "Working Capital ond Fixed Investment: New Evidence on Financing Constrainss," RAND Joumd of Economics (cutumn 1993), pp. 328-42.

Fazzori, Steven M. R. Glenn Hublard, and Bruce C. Petersen. "Financing Constraints and Corporate lnvesment." Brookings Popers on Economic Activity (1988:1), pp. 141-95.

Federal Resenve Bronk of New Yok. Studies on Couses and Consequences of the 1989.1992 Credit Slowdown, Februny 1994.

Fishef, Iring. "The GebtDeflation Theny of Great Depressions." Econometrica 1 (0ctaber 1933), pp. 337.57.

Friedmon, Benipmin M, and Kennett: Ka. Kutner. "Economic Activity and the Short-Term Credit Markets: An Andysis of Prices and Quontities," Brookings Popers on Economic Activity (19932), pp. 193-266.

Gertler, Mark. "Comment" on Chistina D. Romer and Dewid H. Romer, "Credit Chonnel or Credit Actions?: An Interprotation of the Postwar Tronsmissien Mechonism, "in Chonging Copital Morkets: Implicotions for Monefary Policy. Federal Reserve Bank of Mansas City, 1993.

"Financial Capacity and Output Fluctuotions in an Economy with Multi-petiod Finoneid Relotionships," Review of Economic Studies (1992), pp. 45572 .

"Finunciol Structure and Aggregate Economic Activity: An Overwiew," Jound of Money, Credt ond Bonking (August 1988, pout 2), pp. $559-88$.

and Siman Giktrist. "Mhonetay Policy, Business Cycles, and the Behovior of Small Mantofocturing Fitms," Quarterly Jound of Economics (Moy 1994), pp. 309-40.

and ___ "The Role of Credit Merket Impertections in the Monetay Transmission Mechonism: Arguments and Evidence," Scondinawan Jound af Eronomics (No. 1, 1993), pp. 43-64.

Gertler, Mork, and R. Glenn Hubbord. "Conporate Finoncial Policy, Taxation, and Macroeconomic Risk." RAWD Jound of Economics (summer 1993), pp. 286.303. 


\section{REVIILW \\ MAY/JUNE 1995}

and

"Financial Faters in Business

Fluctudions," Finandid Morket Volatilty. Federol Reserve Bank of Konsas City, 1988

Gorton, Gany, and George Pennochi. "Money Makket Funds and Finonce Componies: Are They Banks of the Future?" in Michael Kausner and Lowence I. White, eds, Stuchurol Change in Bonking. Irwin Publishing, 1993 , pip. 173214.

Greenwolk, Buce C, and Joseph E. Stigitz. "Finonciol Market Imperfections and Business Cycles," Quorterly Jound of Economics (Februery 1993), pp. 77.14.

and _._. "Information, Finance Constroints, and Eronomic Activity," in Meir Kohn and S.C. Tsiang, eds. Finonce Constronts, Expectotions, and Economic Activity. Oxford University Press, 1988

Gulley, Jofn, and Edword Shaw. Money in a Theory of Finonce. Broakings institution, 1960.

and "Financial Aspects of Econemic Development," The Americon Fonomic Reviow (September 1955), pp. $515-38$.

Hancok, Dient, Andrew J. Loing and James A. Whicox. "Bank Copital Shacks: Dynemic Effects on Secuities, Loons, and Copitot, "wokking paper (Augesst 1994), Bourd of Governors of the Federal Resserve System.

Hordouvelis, Gikas, and Thieny Wizmon. "The Relative Cost of Copital for Maginal Firms Oves the Business Cyde," Federal Reserve Bank of New York Quorterly Review (outumn 1992), po. 59-68.

Hont, Olives, and Jotn Mare. "A Theory of Debis Based on the Indiendbility of Humon Capital," Discussion Poper No. 129 (1991), London School of Economics, Finencid Matokets Group.

Hittle, Beverly, ond Jeonette Kelleher. "Finencid Morket Evolution and the Interest Sensitivity of Output." Federd Reseve Bonk of New York Quartarly Review (summer 1990), pp. 56-70.

Hoover, Kevin D, and Stephen I. Perez. "Post Hoc Ego Propter Once More: An Evaluation of 'Does Monetary Palicy Matter?' in the Sainit of James Fobin," Joumol of Monetory Economics (August 1994), pp. 4773.

Hosti, Jakeo, Anil K. Kashyep and Dowid Schorstein. "Comporate Structure, Liquidity and thwestment: Evidence fom Japanese Panel Data," Quarterly Jound of Eronomic (Febricry 1991), pp. $33-60$.

Hubbard, R. Glent. Money, the Financiol System and the Economy. Addison-Westey, 1994

and Anil K. Kashyop. "Enternd Ner Worth and the Envestment Process: An Application to U.S. Agriculture," Journol of Polificol Economy (une 1992), pp. 506-34.

and Toni Whited. "Intermal Finence and Firm Investment," Jound of honey, Credit and Bonking (forthcoming)

Jeffee, Dwight, and thomas Russell. "Imperfect lnformotion, Uncertanty ond Credit Rotioning " Ouaterly Joumd of Economics (Noventer 1976), fp. 651-66.
James, Chrisfopher. "Some Evidence on the Uniqueness of Benk Loans," Jound of Financial Economics (1987), ap. 217-36.

Jensen, Mithoel, and Wilion Meckling. "Theory of the Firm: Monogement Behavior, Agency Costs, and Ownership Structure," Jound of Finoncial Econamics (0tober 1976), pp. 305-60

Koshyop, Anil K, and Jereny C Stein. "Monetary Policy ond Bank Lending," in N. Gregory Mankiw, ed., Monetary Policy. University of Chicago Press for the Notiond Berecen of Fronomic Research, 19940, pp. 221-62.

and . "The Impact of Monetary Policy on Bonk Balone Sheets," Conegie-Rochester Conference Series on Public Policy (forthcoming).

and David Wilcox. "Manetary Policy and

Credit Conditions: Evidence from the Composition of External Finance," The American Economic Review (March 1993), wp. 7898.

Owen A. Lamont and Jeremy Stein. "Credit Conditions and the Cyclicat Behovior of Inventories: A Case Study of the 1981-82 Reression," Quorierly Joumal of Economics (August 1994), po. 56592.

King, Robert G., and Chorles Plosser. "Maney, Credit and Prices in a Real Business Cycle," The American Economic Review (June 1984), po. $363-80$

and Ross Levine. "Finance and Growti: Schumpetes thight Be Aight," Quorterty Jound of Economico (August 1993), pp. 717-38.

Wyotaki, Nabuhiro, and tohn Maore. "Credil Cyoles." mimeo (March 1993), London School of Econtmics.

Niesen, Kevin L, and Jom A. Totom. "the Recent Credit Coundr: the Neglected Dimensions," this Review (September/October 1992), pp. 1836 .

Lamont, Owen S. "Corpotote Debt Overhang and Macroeconemic Vulnerobitity," working paper (1993), Massochusetts Institute of Terthology.

Lucos, Robert t. J. "Liquidity and Enterest Rates," Journal of Economic Theory (1990), pp. 237-64.

Lucas, Geborah I., and Robert L. McDonadd. "Bonk Finoning ond Investment Eecisions with Asymatretric Infomation About Loan Quelity," RAMD Jound of Fonomics (winter 1991), po. 86-105.

Lummer, Scott, and Jehin Mccomell. "Furtter Evidence on the Benk Lending Process and Copitol Mokket Response to Bank Loon Agreements," Jounal of Finoncid Economics (1989), pp. 99-122.

Mouskogf, Eiteen. "The Tronsmission Channels of Menetany Policy: How iney Howe Changed," Federd Reserve Bulletin (December 1990), pp. 985-1008.

Minsky, Hyman P. John Moynord Keynes. Columbian Laviversity Press, 1975

"Financial Grisis, Financial Systems, and the Peformance of the Economy" in Commission on Money and Credit, Private Capital Morkets. PrenticeHall, 1964. 
Mishkin, Frederic S. "The Household Bolonce Sheet and the Great Depression," Jounnol of Economic History (1978), pp. 918-37.

Mishkin, Frederic 5. "What Denressed the Consumer?: The Household Botance Sheet and the $1973-75$ Recession," Brookings Popers on Economic Activity (1977:1), pp. 123-64.

Modiglingi, Franco, and Merton Miller. "The Cost of Copital, Cosporoton Finance and the Theory of Investment, ${ }^{\text {The Americon Economic }}$ Review (tune 1958), pp. 26 -197.

Morgan, Dendld P. "The Lending View of Menesany Policy and Bonk Loun Commitments." working paper (1uty 1993), Fedorgl Reserve Bank of Kansos City.

"Asymmetric Effects of Monetary Policy" Federal Reserve Bank of Kansas City Economic Review (second quater 1993), pp. 21-33.

Myers, Stewart, and Nichalas Matuef. "Corporete Finencing and Investment Decisions When Fims Have Intormation thot Investars Do Wot Have," Jound of Finonciol Economies (1984), pp. $187-221$.

Other, Stephen D., and Gernn D. Rudebusch. "Is There o Bonk Credit Channel tor Monetary Polky?" Boand of Govetnots of the Federal Reserve System, Finance ond Economics Rivision Discussion Paper No. 938 (Febuory 1993).

and . Sources of the fituncing hiterachy for Business investment," Review of Eronomics and Statistics (November 1992), pp. 643-54.

Owens, Raymond, and Stocey Schreft. "Identifying Credit Crandhes," Federol Reserve Bank of Richnond Working Paper Mo. 921 (March 1992).

Peek, Joe, and Eric Rosengren. "The Copital Crunch: Neither a Borrower Nor a Lender Be," Joumbl of Money, Credit and Banking (forthooming).

and "The Capital Crunch in Now England."

Federal Reserve Bank of Boston New Englond Economic Review (Moy-lune 1992), pp. 21-31.

Perty, George L., and Chates L. Schutze. "Was this Recession Diffetent? Are They All Differentin?" Brookings Papers on Economic Activity (1993:1), pp. 145-211.

Petersen, Hitchell A, and Raghuram 6. Raian. "The Betefits of FirmCreditor Relotionships: Evidence from Small Bassiness Doto," Journol of Finonce (March 1994), pp. 3-38.

Roney, Valerie. "How Important is the Crefit Channel in the Transmission of Monetary Policy?" Cannegie-Rochester Conterence Series on Public Policy (December 1993), pp. 1-45.

Romer, Chistina D., and Dovid H. Bome: "Credir Channet ar Credit Actions?: An Interpetation of the Postwar Transmissien Methanism," in Chonging Copital Horkets: Implicotions for Monetory Policy. Foderol Reserve Bank of Kansas City, 1993.

and "New Evidence on the Monetury Tronsmission Mechonism," Brookings Papers on Fcomomic Activity (1990:1), pp. 149.213. and "Does Monetary Policy Motter?: A New Test in the Spirit of Friedman and Sehwartz," in Olivier J. Blanchord and Stanley Fischer, eds., Natiand Bureau of Econonic Research Mocroeconomics Annuol. MIT Press, 1989, po. 12170.

Roosa, Robert V. "Interest Rotes ond the Centrd Bank," in Money, Trode, ond Economic Growth: Essays in Honor of John H. Whilioms. Macmillon, 1951.

Rotemberg, lutio I. "A Monatory Equilibrium Modet withi Transoctions Costs," Joumd of Political Economy (February 1984), pp. 40-58.

Gothschild, Michoel, ond Joseph E. Stiglitz. "Equilibrium in Competitive Instence Markets: An Essoy of the tonctionics of Imperfect Informotion," Quorterly Jound of Economics (November 1976), pp. $630-49$

Schreft, Stocey. "Credit Controls: 1980," Federal Reserve Bark of Richnond Economic Roviaw (November-Decenter 1990), pp. 25-55.

Shapiro, Matthew 0. "Federal Reserve Policy: Couse and Effect," in N. Gegory Monkim, ed. Monetary Policy. University of Chicogo Press, 1994, pp. 207-34.

Shane, Steven. "Asymmetic lafomation, Bank Lending, and Implicit Contracts: A Stylized Mode of Custemer Relationships," Journol of Finonce (Septenter 1990), pp. 1069-87.

Stiglitz, Joseph E, and Andrew Weiss. "Codit Rationing in Markets with Imperfect Information," The Americon Economic Review (lune 1981), pp. $393-410$.

Thornton, Dortiel L. "Financial Innowation, Desegulotion and the "Credit View" of Monetory Policy" this Revien (Janeory/February 1994), pp. 31-49.

Townsend, Robert. "Optimal Contracts and Contentitive Morkets with Costly Stute Verification," Joumd of Economic Theory (October 7979), p. 26593

Williomson, Stephen. "Costly Montoring, Optimal Contracts, and Equilibriem Credit Rationing," Querterly loumol of Economics (Febuary 1987), pp. 135-45.

Wonintower, Abert. "The Central Role of Credtit Cunches in Recent Finencial History," Brookings Popers on Economic Activity (1980:2). pp. $277-326$

Zeldes, Stephen P. "Consumption and Liquidity Constraints: An Empisicol Investigotion," Jounal of Politicol Economy (April 1989), pp. 305-46. 


\section{THE FINANCIAL ACCELERATOR AND THE CREDIT VIEW}

There are three basic conclusions of models of financial frictions relating to asymmetric information between borrowers and lenders: (1) Uncollateralized external finance is more costly than internal finance; (2) the spread between the cost of external and internal funds varies negatively with the level of the borrower's internal funds; and (3) a reduction in internal funds reduces the borrower's spending, holding constant underlying investment opportunities. I illustrate these conclusions (and link them to empirical tests of credit view models) below in a simple model of firm investment decisions adapted from Gertler and Hubbard (1988).

Consider two periods-zero and one. In the first, a risk-neutral borrower uses inputs to produce output $Y$ to sell in the second period. These inputs are hard capital, $K-$ say, machinery-and soft capital, $C$-inputs which improve the productivity of hard capital (such as organizational or maintenance expenditures). The production technology is risky, with two possible productivity states, "good" and "bad"; uncertainty is realized after the investment decision is made.

To make the example as simple as possible, suppose the firm can increase the chance of a good output realization if it uses a sufficient quantity of soft capital, where sufficient is defined by a level proportional to the quantity of hard capital used. In particular, let output. $Y$ satisfy:

$$
Y=f(K) \text {, with probability } \pi^{\xi},
$$

and

$$
Y=\alpha f(K) \text {, with probability } \pi^{b} \text {, }
$$

if

and

if

$$
C \geq v K
$$

$$
C<v K \text {, }
$$

where $f(K)$ is twice continuously differentiable, strictly increasing, and strictly con- cave (where $f(0)=0, f^{\prime}(0)=\infty$, and $f^{\prime}(z) \rightarrow 0$ as $z \rightarrow \infty) ; \pi^{g}+\pi^{b}=1 ; 0<\alpha<1 ; v>0$; and the random productivity realization is idiosyncratic.

The structure of the problem guarantees that the firm will either use $v K$ units of soft capital or none. For simplicity, assume that it is always efficient to employ soft capital. (Formally, this requires one to assume that $\left.\left(\pi^{g}+\pi^{b} \alpha\right) /(1+v)>\alpha\right)$.

If there are no informational imperfections, the firm's investment decision is intum itive. It chooses $K$ to satisfy

$$
\left(\pi^{s}+\pi^{h} \alpha\right) f^{\prime}(K)-(1+v) r=0,
$$

where $r$ is the gross interest rate faced by the firm. Equation $2 \mathrm{~A}$ simply states that, at the optimum, the expected marginal benefit from an additional unit of hard capital (given a complementary addition of $v$ units of sof capital) equals the marginal cost of investing. The value of $K$ that satisfies equation A2 call it $K^{*}$ - does not depend on any financial variables; that is, the Modigliani and Miller theorem applies.

The traditional interest rate channel often identifted with the money view mechanism is easy to illustrate in this example. Suppose for simplicity that the interest rate paid on deposits is zero, so that $r$ represents the gross required rate of return on lending. To the extent that an open market sale raises $r$, investment demand falls. This is the usual textbook interest rate channel for monetary policy.

Under asymmetric information, the story is more complicated. Consider, for example, a simple agency problem:

Expenditures on hard capital are observable by outside lenders, while expenditures on soft capital are not. In this case, the manager may be tempted to divert soft capital funds to personal gain. Such perquisite consumption can take a number of forms. For simplicity, assume that the manager can invest the funds (say, in a Swiss bank account) to yield a gross interest rate, $r$. 
Lenders understand this temptation, and modify the financial contract to mitigate incentives to cheat. As shown below, one consequence of this modification is that desired capital, $K^{*}$, may exceed actual capital, $K$, and this gap will depend inversely on the borrower's net worth. Suppose the firm signs a loan contract with a competitive financial intermediary. The firm has some initial liquid asset position, $W$, and collateralizable future profits, $V$, in period one, worth a present value of $V / r$. Hence, the firm's initial net worth is $(W+V / r)$. To make the story interesting, assume that $W<K^{*}$, that is, the firm would like to borrow. (For a richer description of the role of internal net worth in the contracting problem, see Gertler, 1992.)

The firm-intermediary loan contract specifies the amount borrowed (in this case, $(1+v) K-W)$, a payment $P^{g}$ to the intermediary in the event that the project yields the "good" output level, and a payment $P^{b}$ in the event of the "bad" output level. These contractual features are chosen to maximize the firm's expected profits:

(4A) $\left(\pi^{g}+\pi^{b} \alpha\right) f(K)-\pi^{g} P^{g}-\pi^{b} P^{b}$.

From the intermediary's perspective, the loan contract must offer an expected return equal to its opportunity cost of funds, which equals the gross interest rate $r$ times the quantity borrowed:

$$
\text { (5A) } \pi^{g} P^{g}+\pi^{b} P^{b}=r[(1+v) K-W] \text {. }
$$

That is, for simplicity, assume that the intermediary simply channels funds from savers to borrowers, and uses no resources.

Given the underlying incentive problem, the contract must give the firm the incentive to invest in soft capital as a complementary input to hard capital. That is, the contract must satisfy the "incentive constraint:"

$$
\begin{aligned}
& \left(\pi^{g}+\pi^{b} \alpha\right) f(K)-\left(\pi^{g} P^{g}+\pi^{b} P^{b}\right) \\
& \geq\left(\alpha f(K)-P^{b}\right)+r v K .
\end{aligned}
$$

Equation $6 \mathrm{~A}$ just states that the manager's expected gain from honest action exceeds the gain from diverting the soft capital funds to personal use.

One way in which the intermediary could reduce the entrepreneur's temptation to cheat is to increase the amount of $p^{b}$ that the firm must pay the intermediary in the event of a bad outcome. The firm, however, can only credibly promise to pay available assets in the bad state. That is, a limited liability constraint influences the contract:

$$
P^{h} \leq \alpha f(K)+V .
$$

To summarize, the contracting problem involves the selection of $K, P^{g}$ and $P^{h}$ to maximize equation $4 \mathrm{~A}$ subject to equations $5 \mathrm{~A}$, $6 \mathrm{~A}$ and $7 \mathrm{~A}$. One case is easy: As long as the incentive constraint does not bind, actual investment, $K$, simply adjusts to desired investment $K^{*}$. In addition, the pattern of contract payments is indeterminate. (For simplicity, I am abstracting from a richer structure that would lead to both debt and equity contracts and tax considerations; see, for example, Gertler and Hubbard, 1993, for such a treatment.)

When the incentive constraint in equation $6 \mathrm{~A}$ binds, financing and investment decisions are no longer independent. First, note that when the incentive constraint binds, it is desirable to raise $\mathrm{P}^{h}$ to the maximum extent possible; therefore, the limited liability constraint in equation $7 \mathrm{~A}$ also binds. Using $5 \mathrm{~A}$ and $7 \mathrm{~A}$, one can eliminate $\mathrm{P}^{g}$ and $P^{h}$ from equation $6 \mathrm{~A}$, and thereby obtain a relation among $K$, the interest rate and internal net worth:

$$
\begin{aligned}
& \left(\pi^{g}+\pi^{b} \alpha\right) f(k) \\
& -[r(1+2 v)] K+r(W+V / r)=0 .
\end{aligned}
$$

As long as equation $8 \mathrm{~A}$ holds, investment $K$ is an increasing function of the borrower's net worth $(W+V / r)$, holding investment opportunities constant:

$$
\begin{aligned}
& \frac{\partial K}{\partial(W+V / r)} \\
& =\left[(1+2 v)-\left(\pi^{g}+\pi^{b} \alpha\right) f^{\prime}(K) / r\right]^{-1}>0 .
\end{aligned}
$$

The explanation for this effect is that, when the incentive constraint binds, an increase in internal net worth increases the amount of feasible investment.

The existence of the net worth channel precludes neither the traditional interest rate channel nor the bank lending channel. To 
see the former, note an increase in lenders' opportunity cost of funds on account of a monetary contraction reduces desired investment $K^{*}$ (since $K^{*}$ is determined by $\left(\pi^{g}+\right.$ $\left.\left.\pi^{b} \alpha\right) f^{\prime}(K)=(1+v) r\right)$. To see the latter, note that, to the extent that banks face a higher marginal opportunity cost of funds because of a less than perfectly elastic supply schedule for managed liabilities (and borrowers lack access to nonbank finance), the inctease in $r$ lowers both desired and actual investment.

This simple framework is consistent with the description of the financial accelerator mechanism: The cost of uncollateralized external finance exceeds that for internal finance. This gap varies inversely with the internal net worth of the borrower and a decline in net worth reduces the borrowers' spending, all else equal. The framework also yields simple testable predictions related to these money view and credit view arguments: (1) When informational imperfections are ignored, an increase in real interest rates following a monetary contraction should affect investment (broadly defined) similarly for borrowers of a given type (for example, with similar technology and risk characteristics).

(2) If informational imperfections are significant only on the borrower side, all else equal, spending by borrowers with lower levels of internal net worth should fall relative to spending by borrowers with higher levels of internal net worth.
(3) For bank-dependent borrowers, the availability of monitored bank credit can be thought of as a substitute for internal net worth. Changes in the availability of bank credit can influence the ability of bankdependent borrowers to finance spending.

(4) The model's intuition can apply to banks as well as nonfinancial borrowers. A decline in banks' net worth raises banks" opportunity cost of external funds (say, in the $\mathrm{CD}$ market). As a result, the cost of funds to bank-dependent borrowers rises.

(5) If relationships between borrowers and specific banks are important, shocks to the balance sheet positions of individual lenders affect credit availability (at any given open market interest rate) to their borrowers. 